\title{
Pentingnya Ganjaran dan Hukuman terhadap Perilaku Kemandirian Siswa dalam Pendidikan Agama Islam
}

\author{
Syarifah HR DG Tujuh ${ }^{1}$ \\ ${ }^{1}$ IAIN Syaikh Abdurrahman Siddik Bangka Belitung
}

\section{Info Artikel :}

Diterima : 12 April 2019

Direvisi : : 24 Mei 2019

Dipublish : 28 Juni 2019

\section{Kata Kunci: \\ Hukuman \\ Ganjaran \\ Kemandirian \\ Pendidikan Islam}

\section{Keywords:}

Reward

Punishment

Independence

Islamic Education

\begin{abstract}
ABSTRAK
Ganjaran dan hukuman dalam pendidikan merupakan sesuatu yang dibutuhkan dalam pendidikan. Ganjaran merupakan hadiah atas perbuatan baik atau prestasi yang dihasilkan oleh peserta didik, sedangkan hukuman merupakan efek jera terhadap pelanggaran peraturan yang dilakukan oleh peserta didik, namun perlu didingat bahwa hukuman itu tidak berbentuk siksaan tapi mengarah kepada motivasi belajar dan latihan kemandirian. Ganjaran dan hukuman sangat penting untuk melatih kemandirian peserta didik, terutama yang bergelut dalam pendidikan islam, untuk memperoleh pendidikan yang berkualitas.
\end{abstract}

\begin{abstract}
The rewards and punishments are things needed in education. Reward is a gift for good deeds or achievements produced by students, while punishment is a deterrent effect on violations of rules carried out by students, but it should be remembered that the sentence is not in the form of torture but anything that builds motivation to learn and independence training. Rewards and penalties are very important to train the independence of students, especially those who are engaged in Islamic education, to obtain a quality education
\end{abstract}

This is an open access article distributed under the Creative Commons Attribution License, which permits unrestricted use, distribution, and reproduction in any medium, provided the original work is properly cited. C2019 by author.

\author{
Koresponden: \\ Syarifah HR DG Tujuh, \\ Email: queenza.arsyil@gmail.com
}

\section{Pendahuluan}

Setiap manusia berhak mendapatkan perkembangan melalui pendidikan. Pendidikan dan manusia tidak dapat dipisahkan dalam menjalani kehidupan ini, baik pendidikan dalam keluarga, masyarakat maupun bangsa dan negaranya, karena melalui pendidikan akan mampu menciptakan generasi yang berkualitas dan berdayaguna, hal ini sesuai dengan UU No. 20 Tahun 2003 tentang sisitem pendidikan nasional "Pendidikan adalah usaha sadar dan terencana untuk mewujudkan susasana belajar dan proses pembelajaran agar peserta didik secara aktif mengembangkan potensi dirinya untuk memiliki kekuatan spiritual keagamaan, pengendalian diri, kepribadian, kecerdasan, akhlak mulia, serta keterampilan yang diperlukan dirinya, masyarakat, bangsa dan Negara" (Waluya, 2007).

Pendidikan berperan aktif dalam mengembangkan sumber daya manusia, meningkatkan kualitas diri generasi muda, maka dengan segala kesadarannya orang tua punya peran aktif untuk menyekolahkan anak-anaknya. Hal ini dapat dilihat pada saat tahun ajaran baru, jumlah siswa yang mengalami kemajuan yang sangat pesat, dan tidak menutup kemungkinan terjadi masalah yang dihadapi oleh guru, terjadinya penyimpangan dan pelanggaran yang tidak sesuai yang diharapkan, misalnya: terjadinya tawuran antar siswa, bolos sekolah, merokok, dan lain-lain.

Penyimpangan lain yang dilakukan oleh siswa biasanya mereka tidak lagi fokus terhadap pelajaran yang dijelaskan oleh guru di depan kelas, maka guru harus mensiasatinya dengan berbagai metode pembelajaran yang variatif, jangan terpaku pada satu metode yang monoton, harus pandai menciptakan suasana belajar yang menyenangkan. Kemudian guru juga harus mampu memberikan pencegahanpencegahan dalam berbagai macam, seperti adanya tata tertib dalam belajar, peraturan itu harus dipatuhi demi meningkatkan kualitas dan prestasi belajar. Dengan adanya tata tertib ini maka guru bisa mengamati siapa saja yang patuh terhadap aturan dan siapa saja yang melanggarnya, maka disini muncullah ganjaran dan hukuman, tujuannya semata-mata agar siswa termotivasi dan punya semangat untuk belajar.

Efektivitas metode ganjaran dan hukuman berasal dari fakta yang menyatakan bahwa metode ini secara kuat berhubungan dengan kebutuhan individu (Waluya, 2007). Seorang pelajar yang menerima 
ganjaran akan meamahaminya sebagai tanda penerimaan kepribadiannya yang membuat merasa aman karena keamanan atau merasa aman merupakan salah satu kebutuhan psikologis seseorang (Schultz, 1991).

Al Qur'an dan Assunnah telah banyak menggariskan ketentuan-ketentuan dalam membina kepribadian anak didik melalui Pendidikan Islam. Hal tersebut dilakukan melalui bimbingan, asuhan dan didikan serta pengembangan potensi manusia untuk meningkatkan kualitas intelektual dan akhlak yang berpedoman pada syari'at agama. Pendidikan merupakan proses dan tingkah lakuseseorang atau kelompok orang dalam usaha mendewasakan manusia melalui upaya pengajaran dan pelatihan (Sabartiningsih, Muzakki, \& Durtam, 2018).

Pemberian ganjaran kepada peserta didik yang berbuat kebaikan akan memberikan pengaruh besar, sebab ganjaran baik itu pujian maupun penghargaan akan memberikan motivasi bagi mereka untuk memperbaiki dan meningkatkan perilaku supaya lebih baik dari yang sebelumnya. Dalam memberikan ganjaran hendaknya harus diperhatikan sejumlah masalah penting sehingga ganjaran tersebut akan bernilai dan efektif. Tanpa mempertimbangkan faktor tersebut, maka ganjaran tidak akan berpengaruh, atau bahkan sebaliknya akan memberikan dampak yang negative bagi peserta didik. Dalam memberikan ganjaran hendaklah diperhatikan hal-hal berikut, yaitu:

Pertama, Ganjaran yang diberikan kepada seseorang haruslah bernilai bagi orang itu. Sebab sebuah hadiah bagi seseorang mungkin dianggap bernilai, tapi tidak bagi yang lain. Kedua, Ganjaran yang di berikan hendaknya memiliki nilai pendidikan, artinya ganjaran yang diberikan harus dapat membuat anak segera tahu bahwa tingkah lakunya itu baik dan harus dapat merangsang anak untuk dapat selalu melakukan tindakan yang positif. Ketiga, ganjaran yang diberikan harus dapat memotivasi anak untuk mengulangi tingkah laku yang baik

Anak umumnya akan bereaksi positif terhadap penerimaan lingkungan yang diekspresikan lewat hadiah. Hal ini mendorong mereka bertingkah laku baik agar mendapat hadiah lebih banyak. Keempat, Tidak boleh ada jarak yang sangat jauh antara ganjaran dengan perbuatan baik yang telah dilakukan oleh peserta didik tersebut. Hal ini karena, apabila pemberian ganjaran berjauhan waktunya maka pengaruhnya tidak besar, bahkan mungkin akan hilang sama sekali atau kurang menarik.

Dalam metode pemberian hukuman dan ganjaran ini bnyak memberikan manfaat kepada peserta didik, diantaranya meningkatkan motivasi belajar peserta didik, melatih kedisiplinan, dan melatih kemandirian. Maka dari sini penulis ingin mengkaji kemandirian yang seperti apa yang dihasilkan ketika anak diberikan ganjaran atau hukuman dalam pembelajaran.

\section{Metode}

Penelitian yang digunakan dalam mengkaji beberapa teori adalah kualitatif. Metode penelitian yang digunakan berupa kajian pustaka atau studi kepustakaan, yaitu studi yang membahas teori-teori yang relevan dengan masalah-masalah penelitian. Adapun masalah pada penelitian ini adalah "pentingnya ganjaran dan hukuman pada pembelajaran pendiidkan agama Islam"

Pada bagian ini dilakukan pengkajian mengenai konsep dan teori yang digunakan berdasarkan literatur yang tersedia, terutama dari artikel-artikel yang dipublikasikan dalam berbagai jurnal ilmiah. Kajian pustaka berfungsi untuk membangun konsep atau teori yang menjadi dasar studi dalam penelitian (Sujarweni, 2014).

Kajian pustaka atau studi pustaka merupakan kegiatan yang diwajibkan dalam penelitian, khususnya penelitian akademik yang tujuan utamanya adalah mengembangkan aspek teoritis maupun aspek manfaat praktis. Sehingga dengan menggunakan metode penelitian ini penulis dapat dengan mudah menyelesaikan masalah yang hendak diteliti (Sukardi, 2005).

Sehingga dengan menggunakan metode penelitian ini penulis dapat dengan mudah menyelesaikan masalah yang hendak diteliti.

\section{Hasil dan Pembahasan}

1. Hakekat ganjaran/ hadiah dalam Islam

Ganjaran atau hadiah dalam bahasa Indonesia dapat diartikan dengan upah, pahala, balasan dan pemberian penghargaan. Maka dalam hal ini ganjaran dalam pendidikan adalah memberikan hadiah atau penghargaan kepada peserta didik terhadap prestasi-prestasi yang telah dicapainya. Oleh karena itu ganjaran merupakan alat pendidikan representative yang bersifat menyenangkan dan membangkitkan atau mendorong peserta didik untuk berbuat sesuatu yang lebih berbaik dan bermanfaat terutama bagi anak yang malas dan memiliki prestasi yang kurang baik. 
Dalam memberikan ganjaran, pendidik harus menyesuaikan dengan perbuatan-perbuatan atau prestasi yang dicapai peserta didik jangan sampai menebalkan sifat materialistis pada anak didik, kemudian juga pendidik harus menghilangkan anggapan kepada anak didik terhadap upah atau balas jasa terhadap apa yang sudah dilakukan, jangan sampai peserta didik terlena dengan ganjaran

Dalam bahasa arab ganjaran diistilahkan dengan tsawab, di dalam Al Qur'an, dalam menunjukkan apa yang diperbuat oleh seseorang dalam kehidupan ini atau di akhirat kelak karena amal perbuatan yang baik. Dalam surah Ali Imran (3) : 148, Allah berfirman:

"Maka Allah berikan ganjaran kepada mereka di dunia dan akhirat dengan ganjaran yang baik. Dan Allah cinta kepada orang-orang yang berbuat baik"

Kelebihan ganjaran di akhirat berasal dari sumbernya yang unggul. Hal ini diilustrasikan mengapa Nabi Muhammad SAW hanya mengharap balasan dari Allah semata-mata. Maka pelajar menurut sistem pendidikan Islam, harus diberi motivasi sedemikian rupa.

Pemberian ganjaran tidak semata-mata berupa materi, uang, dll. Seorang guru yang bijaksana harus memulai pendidikan dengan memberi hadiah atau berupa pujian-pujian yang menambah gairah dan semangat belajar siswanya. Reward diberikan dengan syarat: a) hanya diberikan pada anak yang telah mendapatkan prestasi yang baik, b) jangan menjanjikan ganjaran/hadiah lebih dulu sebelum anak berprestasi. c) diberikan dengan hati-hati jangan sampai anak menganggapnya sebagai upah, d) jangan sampai menimbulkan kecemburuan bagi anak yang lain, namun sebaiknya harus menimbulkan semangat dan motivasi bagi anak didik yang lain. Adapun tujuan utama seorang guru memberikan ganjaran adalah: a. Merangsang motivasi belajar anak terutama bagi anakyang malas dan lemah dalam proses pembelajaran. b. Mendorong agar anak lebih meningkatkan diri lagi untuk hal-hal yang baik, c. Menambah kegiatannya atau kegairahannya dalam belajar (Hamid, 2006).

Menurut Muhammad Jameel Zeeno, ganjaran bisa berupa :

a. Pujian yang Mendidik

Seorang guru atau pendidik yang baik hendaknya memberi pujian kepada siswa ketika ia melihat tanda-tanda yang baik dan terpuji pada diri dan perilaku siswanya. Hal yang sama juga dilakukan pada saat pendidik melihat kesungguhan siswanya. Saat ada siswa yang memberikan jawaban dari pertanyaan yang diberikan si guru, ia harus mengatakan, "jawaban yang kamu berikan baik sekali, semoga Allah memberkatimu", kalimat-kalimat lembut seperti ini selalu memberi motivasi bagi siswa dan memperkuat semangat maknawi dalam jiwanya. Kalimat itu juga akan meninggalkan pengaruh yang baik sekali dalam jiwanya, yang dapat menyebabkan ia menyukai guru dan sekolahnya. Otaknyapun menjadi mudah menerima pelajaran. Pada waktu yang sama, ia juga dapat memberi dorongan semangat pada siswa-siswa yang lain untuk menjadi teladan mereka dalam etika, perilaku, dan kesungguhan, agar mereka dapat juga memperoleh pujian. Hal ini lebih baik bagi mereka daripada memberi sanksi fisik yang mereka dapati.

b. Memberi Hadiah

Sebagaimana umumnya kita ketahui dan maklumi bersama, karakter anak pasti lebih menyukai mendapat hadiah yang sifatnya berwujud materi (Hamid, 2006). Ia pun pasti akan berusaha keras untuk mendapatkannya. Oleh karena itu, seorang hendaknya merespons apa yang disukai oleh seorang anak. Ia harus bisa menberikan hadiahhadiah tersebut pada kesempatan yang tepat. Seorang siswa yang rajin, berakhlak baik, dan yang dapat menjalankan kewajibannya pada Tuhannya, seperti shalat dan amal-amal baik, ia layak memperoleh hadiah dari gurunya. Kala itulah, anak itu akan menemukan jiwanya senang sekali menerima itu di hadapan temantemannya. Untuk diketahui, pada usia pelajar, jiwa seorang anak telah dipenuhi instink suka memiliki.

c. Mendo'akan

Seorang guru hendaknya memberi motivasi dengan mendo'akan siswanya yang rajin dan sopan. Guru bisa saja mendoakannya dengan mengatakan," Semoga Allah selalu memberimu taufik dan hidayah,"Saya berharap masa depanmu cemerlang." Sebaliknya, untuk siswa yang kurang rajin atau tidak melakukan hal yang baik, maka si guru mendoakannya dengan mengatakan,"Semoga Allah memberi petunjuk dan memperbaikimu".

d. Papan Prestasi

Papan prestasi yang ditempatkan di lokasi strategis pada lingkungan sekolah merupakan salah satu hal yang bermanfaat. Pada papan itu, dicatat namanama siswa yang berprestasi baik dari prilaku, kerajinan, kebersihan, maupun dalam pelajarannya. Pengumuman ini memberi motivasi pada siswa yang lain untuk meneladani teman-temannya itu, agar para siswa yang lain juga berkeinginan namanya bisa tercatat dalam papan itu. 
e. Menepuk Pundak

Pada saat salah seorang siswa maju ke depan kelas untuk menjelaskan pelajaran atau mengerjakan dan menyelesaikan soal dengan benar, menyampaikan hafalannya dengan baik, memecahkan suatu masalah, atau memperdengarkan salah satu surah dalam al-Qur'an, maka seorang guru sudah sepantasnya bila menepuk pundak siswa tersebut sebagai reaksi rasa senang, rasa bangga dan penghargaan kepadanya.

\section{Hakekat Hukuman dalam Islam}

Hukuman dalam pengertian etimologi merupakan siksaan atau akibat atas pelanggaran aturan atau Undang-undang yg dilakukan oleh seseorang dalam hal ini peserta didik. Menurut Athiyah Al Abrasyi dalam karyanya At Tarbiyah Al Islamiyah, hukuman merupakan lebih sebagai usaha edukatif untuk memperbaiki dan mengarahkan siswa kea rah yang benar bukan semata-mata praktek hukuman dan siksaan yang membatasi kreatifitas dan prestasi siswa melainkan lebih mengembangkan potensi seseorang dan mengembalikan motivasinya menjadi pribadi yang semangat, kreatif dan produktif. Bisa dibilang hukuman itu merupakan alat atau sarana pendidikan yang sesekali diperlukan oleh guru.

Hukuman merupakan sesuatu yang disyariatkan dan merupakan salah satu sarana dalam pendidikan dan sesekali bisa menjadi hal yang diperlukan oleh pendidik. Disini guru harus sangat berhati-hati, jangan sampai siswa yang diberikan hukuman merasa disiksa. Alat pendidikan yang berupa hukuman ini merupakan sesuatu yang tidak menyenangkan sebagai imbalan dari perbuatan yang tidak baik, akan tetapi perlu diingat bahwa dalam pemberian hukuman tersebut, seorang guru harus memiliki motivasi agar hukuman yang diberikan kepada peserta didik bisa menjadi motif yang baik bagi peserta didik tersebut (Muzakki, 2017).

Tujuan memberikan hukuman kepada peserta didik tidak lain hanyalah untuk memberikan bimbingan dan perbaikan. Oleh karena itu, harus diperhatikan watak an kondisi anak yang bersangkutan sebelum seorang guru menjatuhkan hukuman terhadapnya

Guru harus memberikan keterangan kepadanya tentang kekeliruan yang dilakukannya, dan memberinya semangat untuk memperbaiki dirinya, serta memaafkan kesalahan-kesalahan dan kealpaannya ketika anak yang bersangkutan telah memperbaiki dirinya. Seorang guru diharapkan memiliki prinsip lebih baik salah mema"eafkan dari pada salah menghukum. Rasulullah saw bersabda: "Dari Aisyah ra, dia berkata: "Rasulullah saw bersabda: "Tinggalkanlah hudud dari kaum muslimin semampu kalian. Jika ada jalan keluar, maka berikanlah jalannya. Sesungguhnya seorang imam (pemimpin) jika dia salah mema "afkan, itu lebih baik dari pada salah menghukumi" (HR At-Tirmidzi) (Muhammad 'Athiyyah Al-Abrāsyi. At-Tarbiyah al-Islāmiyah. Terj. Abdullah Zaky al- Kaaf. Bandung: Pustaka Setia. 2003, hlmn 165-166)

\section{Karakter Kemandirian Peserta Didik}

Kemandirian menurut istilah kemandirian merupakan keadaan dapat berdiri sendiri, tidak tergantung terhadap orang lain (Departemen P dan K, 1994: 625). Prayitno (2009:26), mengungkapkan bahwa kemandirian merupakan kondisi pribadi yang telah mampu mengembangkan pancadaya kemanusiaan bagi tegaknya hakikat manusia pada dirinya sendiri dalam bingkai dimensi kemanusiaan.

Siswa yang mandiri adalah siswa yang mampu mewujudkan kehendak atau realisasi diri tanpa bergantung dengan orang lain. Untuk menjadi madiri seorang perlu memahami dan menerima diri secara objektif, positif dan dinamis, mampu mengambil keputusan, mengarahkan diri sendiri, serta mewujudkan diri sendiri. Begitu pula dalam kegiatan pembelajaran, siswa harus mampu menerima diri dan lingkungan, berani mengambil keputusan dalam belajar, mengarahkan dirinya sesuai dengan tujuan yang telah ditetapkan serta mewujudkan diri sendiri untuk mencapai tujuan pembelajaran yang diinginkannya.

Dalam pembelajaran untuk menjadi pribadi mandiri itu tidaklah mudah, ada beberapa factor yang mempengaruhi, diantaranya factor internal dan eksternal siswa (Slameto, 2003:54), teman sebaya, (Damin, 2010:141) genetik atau keturunan dari orang tua, pola asuh orang tua, sistem pendidikan di sekolah serta sistem kehidupan di masyarakat (Asrosi, 2011:118). Apabila siswa tidak bisa menyaring kondisi lingkungan yang akan berdampak negatif, maka kondisi itu akan berakibat buruk kepada siswa, sehingga kemandirian belajar siswa tidak akan tercipta dengan sendirinya, atau menjadi lebih buruk lagi, siswa tidak akan memiliki kemandirian belajar. Ketidakmandirian ini akan berakibat pada rendahnya motivasi belajar siswa, ketidakmampuan dalam mengambil keputusan, rendahnya nilai hasil belajar serta ketidakberfungsian siswa tersebut dalam masyarakat. Ketidakmandirian belajar siswa bisa diatasi melalui layanan bimbingan kelompok dengan topik tugas. Amin (2010:328) menyatakan bahwa "sejumlah masalah yang umumnya dihadapi oleh para 
Kemandirian (11-12 tahun) Pada usia ini anak telah memiliki kemandirian. Kemandirian ini ditandai dengan siap menerima resiko jika tidak mentaati peraturan. Contoh kemandirian pada pribadi rasul adalah saat beliau mengikuti pamannya untuk berniaga ke negeri Syam. Pada saat itu Rasulullah telah memiliki kemandirian yang hebat, tidak cengeng, kokoh, sampai mau mengikuti perjalanan yang jauh dengan pamannya tersebut, hingga pada saat itu seorang pendeta Bukhaira menemukan tandatanda kenabian pada beliau.

Bermasyarakat (13 Tahun) Pada fase ini anak sudah mulai memiliki kemampuan untuk bermasyarakat dengan berbekal pengalaman-pengalaman yang didapat pada fase-fase sebelumnya. Kehidupan dalam masyarakat lebih kompleks dari kehidupan keluarga, anak anak mengenal banyak karakter manusia selain karakter orang-orang yang dia temui di dalam keluarganya.

Jika merujuk kepada klasifikasi perkembangan karakter tersebut, anak usia SD ada pada fase tanggung jawab (7-8), peduli (910), dan kemandirian (11-12). Pada usia 7-8 diawali dengan perkenalan anak pada lingkungan baru di sekolah, yang sebelumnya anak hanya mengenal lingkungan rumah, maka pada fase ini anak harus mampu beradaptasi dengan lingkungan baru, anak mulai memiliki rasa tanggung jawab terhadap tugas barunya yaitu belajar dan mengenal lingkungan baru. kemandirian belajar siswa.

Kemandirian belajar adalah suatu sikap siswa yang memiliki karakteristis berinisiatif belajar, mendiagnosis kebutuhan belajar, menetapkan tujuan belajar, memonitor, mengatur dan mengontrol kinerja atau belajar, memandang kesulitan sebagai tantangan, mencari dan memanfaatkan sumber belajar yang relevan, memilih dan menerapkan strategi belajar, mengevaluasi proses dan hasil belajar, serta self-concept (konsep diri). Dengan memiliki kemandirian belajar siswa akan mempunyai tujuan yang jelas, dapat menilai diri sendiri, mempertimbangkan kemajuan belajar, seperti pandangan dan kepercayaan yang tinggi tentang kemampuan dirinya, menilai pembelajaran, faktor yang berpengaruh dalam belajar, dan antisipasi dampak (self-efficacy) selama proses pembelajaran (Choridah, 2013).

Menegaskan bahwa ciri utama dalam belajar mandiri bukanlah ketiadaan guru atau teman sesama siswa, atau tidak adanya pertemuan tatap muka di kelas, melainkan adanya pengembangan kemampuan siswa untuk melakukan proses belajar yang tidak tergantung kepada faktor guru, teman, kelas dan lain-lain. Tingkat kemandirian belajar siswa dapat ditentukan berdasarkan seberapa besar inisiatif dan tanggung jawab siswa untuk berperan aktif dalam hal perencanaan belajar, proses belajar maupun evaluasi belajar. Semakin besar peran aktif siswa dalam berbagai kegiatan tersebut, mengindikasikan bahwa siswa tersebut memiliki tingkat kemandirian belajar yang tinggi (Pannen, Mustafa, \& Sekarwinahyu, 2001).

Menurut Suparno (2002) kemandirian penting dalam belajar karena dengan adanya kemandirian belajar, keberhasilan dan prestasi belajar akan mudah diperoleh. Diantara bentuk- bentuk kemandirian belajar siswa adalah kesadaran diri untuk belajar, adanya rasa percaya diri dalam menyelesaikan tugastugasnya, tidak mencontoh teman, tidak mencontek buku saat ujian dan memiliki pribadi yang berkualitas (eksploratif, kreatif dan integral) (Nuridawani, Munzir, \& Saiman, 2015).

Kemandirian dalam belajar bagi siswa merupakan suatu langkah yang efektif dan efisien dalam memaksimalkan kemampuan siswa tanpa harus bergantung pada guru, sehingga proses belajar mengajar akan lebih optimal. Dari hasil pengamatan awal dan wawancara dengan guru dapat diketahui bahwa kebanyakan siswa belum mampu secara mandiri untuk menemukan, mengenal, memerinci hal-hal yang berlawanan dan menyusun pertanyaan-pertanyaan yang timbul dari masalahnya. Siswa hanya menerima apa yang disajikan oleh guru dan sangat bergantung pada guru. Upaya untuk mencari informasi dari media lain sangat kurang. Oleh karena itu, kemandirian belajar diperlukan agar siswa mempunyai tanggung jawab dalam mengatur dan mendisiplinkan dirinya, serta dalam mengembangkan kemampuan belajarnya atau kemauan sendiri.

\section{Kesimpulan}

Dari hasil kajian dapat dikatakan bahwa ada hubungan antara pemberian reward dan punishment dengan sikap kemandirian dalam Pendidikan Islam terhadap siswa. Penelitian ini menggunakan pendekatan kualitatif dengan menggunakan berbagai referensi dari berbagai karya ilmiah. Hal ini menunjukkan bahwa pemberian reward dan punishment menjadi salah satu sarana untuk melatih kemandirian siswa terhadap kemandirian peserta didik. 


\section{Referensi}

Choridah, D. T. (2013). Peran pembelajaran berbasis masalah untuk meningkatkan kemampuan komunikasi dan berpikir kreatif serta disposisi matematis siswa SMA. Infinity Journal, 2(2), 194-202.

Hamid, R. (2006). Reward dan Punishment dalam Perspektif Pendidikan Islam. Ittihad Jurnal Kopertis Wilayah XI Kalimantan, 4(5), 65-76.

Muzakki, J. A. (2017). Hakekat Hukuman Dalam Pendidikan Islam. Halaqa: Islamic Education Journal, $1(2), 75-86$.

Nuridawani, N., Munzir, S., \& Saiman, S. (2015). Peningkatan kemampuan penalaran matematis dan kemandirian belajar siswa Madrasah Tsanawiyah (MTs) melalui pendekatan Contextual Teaching and Learning (CTL). Jurnal Didaktik Matematika, 2(2).

Pannen, P., Mustafa, D., \& Sekarwinahyu, M. (2001). Konstruktivisme dalam pembelajaran. Jakarta: Dikti.

Sabartiningsih, M., Muzakki, J. A., \& Durtam, D. (2018). IMPLEMENTASI PEMBERIAN REWARD DAN PUNISHMENT DALAM MEMBENTUK KARAKTER DISIPLIN ANAK USIA DINI. AWLADY: Jurnal Pendidikan Anak, 4(1), 60-77.

Schultz, D. (1991). Psikologi pertumbuhan, model-model kepribadian sehat. Kanisius.

Sujarweni, V. W. (2014). Metodologi penelitian: Lengkap, praktis, dan mudah dipahami. Yogyakarta: Pustakabarupress.

Sukardi, M. P. P. (2005). Kompetensi dan Praktiknya. Jakarta: Bumi Aksara.

Waluya, B. (2007). Sosiologi: Menyelami fenomena sosial di masyarakat. PT Grafindo Media Pratama. 